\title{
Pengayaan biskuit dengan fortifikasi fraksi tidak tersabunkan mengandung senyawa bioaktif multi komponen dari distilat asam lemak minyak sawit
}

\author{
Enrichment biscuits with fortification unsaponiable fraction contains bioactive compound \\ from palm fatty acid distillate \\ Kgs Ahmadi $^{1)^{*}}$, Teti Estiasih ${ }^{2)}$, Wahyu Erwin Firmansyah ${ }^{2)}$ \\ ${ }^{1}$ Program Studi Teknologi Industri Pertanian, Universitas Tribhuwana Tungadewi, \\ Malang, Jawa Timur \\ ${ }^{2}$ Jurusan Teknologi Hasil Pertanian, Universitas Brawijaya, Malang, Jawa Timur \\ *Email korespondensi: kgs.ahmadi@yahoo.com
}

Informasi Artikel:

Dikirim: 03/06/2021; disetujui: 25/07/2021; diterbitkan: 28/09/2021

\begin{abstract}
Palm Fatty Acid Distillate (PFAD) is a by product of CPO (crude palm oil) physical refining. PFAD containing multicomponent bioactive compounds such as tocopherols, tocotrienols, phytosterols, and squalene which accumulated in unsaponifiable fraction $(U F)$ and can be separated by saponification. Utilization of bioactive compounds can be applied on food products by fortification into biscuits. The research aimed to determine the effect of addition level of UF from PFAD on physical and organoleptics of the biscuits and also to determine chemical characteristic and bioactive compounds from the best treatment biscuit. The method used a completely randomized design with one factor, namely the level of addition of the UF from PFAD consisted of 6 treatments and was repeated four times. Data were analyzed using Analysis of Variance (ANOVA), then continued using the Duncan's Multiple Range Test (DMRT) with significance level of 5\%. The best treatment in this study was a treatment which contained $0.5 \%(w / w)$ of the UF from PFAD. The best biscuit had chemichal characteristics included those were the water content $1.81 \pm 0.06 \%, 2.10 \pm 0.06 \%$ ash content, $27.98 \pm 0.54 \%$ fat content, $8.04 \pm 0.13 \%$ protein content, $0.22 \pm 0.02 \%$ crude fiber content, $60.07 \pm 0.66 \%$ carbohydrate content, $2.66 \pm 0.00002 \% \mathrm{FFA}$, and $7.10 \pm 0.19 \mathrm{mek} / \mathrm{kg}$ total oxidation. The best biscuit contained bioactive compounds such as 147.19 ppm $\alpha$-tocotrienol, $190.30 \mathrm{ppm} \delta$-tocotrienol, $68.091 \mathrm{ppm} \gamma$-tocotrienol, 5,848.45 ppm $\beta$-sitosterol, 143.97 ppm stigmasterol, 621.09 ppm campesterol, and squalene content 3,284.50 ppm.
\end{abstract}

Keywords: Bioactive Compounds, Biscuits, Fortification, PFAD, UF

\section{ABSTRAK}

Distilat asam lemak minyak sawit (DALMS) merupakan produk samping dari proses pemurnian fisik minyak sawit kasar atau CPO (crude palm oil). DALMS mengandung senyawa bioaktif multikomponen seperti tokoferol, tokotrienol, fitosterol, dan skualen yang terakumulasi dalam fraksi tidak tersabunkan (FTT) dan dapat dipisahkan melalui proses saponifikasi. Pemanfaatan senyawa bioaktif tersebut dapat diaplikasikan pada produk pangan dengan cara fortifikasi pada biskuit. Penelitian ini bertujuan untuk mengetahui pengaruh tingkat penambahan FTT DALMS terhadap sifat fisik dan organoleptik biskuit serta untuk mengetahui karakteristik kimia dan senyawa bioaktif biskuit perlakuan terbaik. Metode penelitian yang digunakan adalah Rancangan Acak Lengkap (RAL) dengan 1 faktor, yaitu tingkat penambahan FTT yang terdiri dari 6 perlakuan dan diulang 4 kali. Data yang diperoleh dianalisis menggunakan Analysis of 
Variance (ANOVA) dan dilanjutkan dengan Duncan Multiple Range Test (DMRT) dengan taraf nyata 5\%. Perlakuan terbaik pada penelitian ini yaitu pada biskuit dengan penambahan FTT DALMS $0.5 \%(\mathrm{~b} / \mathrm{b})$. Karakteristik kimia biskuit terbaik yaitu kadar air $1.81 \pm 0.06 \%$, kadar abu $2.10 \pm 0.06 \%$, kadar lemak $27.98 \pm 0.54 \%$, kadar protein $8.04 \pm 0.13 \%$, kadar serat kasar $0.22 \pm 0.02 \%$, kadar karbohidrat $60.07 \pm 0.66 \%$, ALB $2.66 \%$, total oksidasi $7.10 \pm 0.19 \mathrm{mek} / \mathrm{kg}$. Biskuit perlakuan terbaik mengandung senyawa bioaktif antara lain: $\alpha$-tokotrienol sebesar $147.19 \mathrm{ppm}, \delta$-tokotrienol sebesar $190.30 \mathrm{ppm}, \Upsilon$-tokotrienol sebesar $68.091 \mathrm{ppm}, \beta$-sitosterol sebesar 5,848.45 ppm, stigmasterol sebesar $143.97 \mathrm{ppm}$, dan kampesterol sebesar $621.09 \mathrm{ppm}$, dan kadar skualen sebesar 3,284.50 ppm.

Kata Kunci: Biskuit, Fortifikasi, DALMS, FTT, Senyawa Bioaktif

\section{PENDAHULUAN}

Minyak sawit merupakan komoditas hasil perkebunan yang mempunyai peranan cukup penting di Indonesia. Pada tahun 2009 produksi minyak sawit dalam bentuk CPO (Crude Palm Oil) mencapai 21.39 juta ton, meningkat menjadi 27.8 juta ton pada tahun 2013, dan diperkirakan meningkat $5.47 \%$ menjadi 30.95 juta ton pada tahun 2015 (Ulum dan Hariyanto, 2015), dengan luas area sebesar 11,44 juta hektar (Soependi dan Arianto, 2014). Selama proses pemur-nian minyak kelapa sawit dihasilkan distilat asam lemak minyak sawit (DALMS) pada tahap deasidifikasi-deodorisasi yang masih mengandung beberapa senyawa bioaktif multikomponen. DALMS yang dihasilkan mencapai 5\% dari berat minyak sawit (Zulkifli dan Estiasih, 2009).

Menurut Estiasih et al. (2013), DALMS mengandung senyawa bioaktif multikom-ponen yang masih belum banyak dieksplor. DALMS mengandung asam lemak dan gliserida sebanyak 96.1\%, senyawa bioaktif seperti tokoferol dan tokotrienol $0.48 \%$, fitosterol $0.37 \%$, skualen $0.76 \%$, dan hidro-karbon lainnya $0.71 \%$. Senyawa bioaktif yang terkumpul dalam DALMS dapat dimanfaatkan sebagai sumber senyawa bioaktif yang terakumulasi dalam fraksi tidak tersabunkan (FTT) dan dapat dipisah-kan melalui proses saponifikasi (Liu et al., 2008). FTT dimanfaatkan sebagai sumber vitamin E (tokoferol dan tokotrienol), fitosterol, skualen, pigmen, dan senyawa hidrokarbon (Salimon el al, 2012). Senyawa biokatif dalam FTT DALMS secara umum mempunyai efek hipokolesterolemik sehingga dapat mencegah penyerapan kolesterol berlebih. Dengan demikian, FTT berpotensi sebagai sumber senyawa bioaktif multikomponen yang dapat bersinergi untuk mengatasi penyakit dan masalah fisiologis.

Salah satu aplikasi FTT DALMS yaitu dengan cara fortifikasi pada produk pangan seperti biskuit. Biskuit merupakan makanan kecil (snack) yang biasanya dibuat dari bahan dasar tepung terigu atau tepung jenis lainnya. Biskuit sifatnya mudah dibawa karena volume dan beratnya yang kecil dan umur simpannya relatif lama (Hadi, 2007). Konsumsi rata-rata kue kering termasuk biskuit di kota besar dan pedesaan di Indonesia mencapai $0.40 \mathrm{~kg} / \mathrm{kapita} / \mathrm{tahun}$ (Subagjo, 2007). Oleh karena itu biskuit memiliki potensi yang cukup besar untuk dijadikan produk pangan yang difortifikasi zat gizi dari FTT DALMS. Hal tersebut didukung dengan kemudahan biskuit difortifikasi zat gizi dan didukung oleh tingginya tingkat konsumsi biskuit di Indonesia.

Penelitian ini bertujuan untuk mengetahui pengaruh tingkat penambahan FTT DALMS terhadap sifat fisik dan organoleptik biskuit, untuk mengetahui konsentrasi terbaik pada tingkat penambahan FTT DALM, serta untuk mengetahui karakteristik kimia dan senyawa bioaktif biskuit perlakuan terbaik. 


\section{BAHAN DAN METODE}

\section{Bahan}

Bahan yang digunakan pada penelitian ini yaitu DALMS yang diperoleh dari industry pengolahan CPO PT.Salim Ivomas Pratama (Bimoli) di Surabaya. Bahan saponifikasi yaitu asam askorbat, $\mathrm{KOH} 50 \%$, etanol 96\%, heksana, akuades, dan gas nitrogen. Bahan pembuatan biskuit terdiri dari tepung terigu, margarin, gula halus, vanili, baking powder, garam, susu bubuk, kuning telur, dan FTT DALMS. Bahan analisis kimia terdiri dari petroleum eter (PE), $\mathrm{H}_{2} \mathrm{SO}_{4}, \mathrm{NaOH}, \mathrm{K}_{2} \mathrm{SO}_{4}$, etanol, metanol, $\mathrm{HCl}$, reagen Nelson $\mathrm{A}$ dan $\mathrm{B}$, raegen Arsenomolibdat, asam borat, tablet kjedahl, indikator PP, indikator metil red, kloroform (Merck), heksana, benzene, reagen $\mathrm{p}$ anisidin, ammonium tiosianat, $\mathrm{HCl} 37 \%$, ferro sulfat, $\mathrm{FeCl}_{3}, \mathrm{BaCl}_{2}$, dan $\mathrm{H}_{2} \mathrm{O}_{2}$. Bahan kimia untuk analisis senyawa bioaktif yaitu etanol, methanol (HPLC grade), aquabides, standar tokoferol ( $\alpha$-tokoferol), standar tokotrienol ( $\alpha$-tokotrienol, $\delta$-tokotrienol, $\Upsilon$ tokotrienol) "Santa Cruz Biotechnology", dan standar fitosterol $(\beta$-sitosterol, stigmasterol, dan kampesterol) "SigmaAldrich" dan MSTFA (N-Methyl-Ntrimethylsilyl trifluoroacetamide) "Santa Cruz Biotechnology".

\section{Alat}

Peralatan yang digunakan meliputi timbangan digital, mixer (Miyako), sendok, wadah plastik, cetakan biskuit, oven listrik, timbangan analitik (Denver Instrumen $M$ 310), glassware, shaker waterbath (Memmert), termometer, corong pemisah $500 \mathrm{ml}$ (Duran), rotary vacuum evaporator (Buchi Rotarovorator R-200), freezer. Alat yang digunakan untuk analisis biskuit yaitu color reader (Minolta Chromameter CR 400), tensile strength (Imada), texture analyzer, oven, muffle furnace, soxhlet, desikator, reflux, labu kjedahl, distilator, buret $25 \mathrm{ml}$, shaker, spektrofotometer (LaboMed), vortex, sentrifuge $1500 \mathrm{rpm}$, HPLC (Shimadzu LC-20 AT), GC-MS (Shimadzu QP2010S), mikropipet, dan micropore.

\section{Metode}

Metode penelitian yang digunakan adalah Rancangan Acak Lengkap (RAL) dengan 1 faktor yang terdiri dari 6 level (b/b) $(0 \%, 0.5 \%, 1 \%, 1.5 \%, 2 \%, 2.5 \%)$ sehingga didapatkan 6 perlakuan. Setiap perlakuan diulang sebanyak 4 kali sehingga diperoleh 24 satuan percobaan. Data yang didapatkan dianalisis dengan menggunakan Analysis of Variance (ANOVA). Apabila terdapat pengaruh nyata maka dilanjutkan dengan Duncan Multiple Range Test (DMRT) dengan taraf nyata $5 \%$. Analisis perlakuan terbaik biskuit didapatkan dari hasil analisis fisik dan organoleptik menggunakan metode Multiple Atribute (Zeleny, 1982). Penelitian yang dilakukan meliputi proses saponifikasi DALMS (Modifikasi Ahmadi, 1997), proses pembuatan biskuit (Modifikasi Rahmawati, 2014), pengamatan parameter fisik (tekstur, daya patah, daya kembang, densitas kamba, warna) dan organoleptik (Rahayu, 2001), ekstraksi lipid dari biskuit perlakuan terbaik (Bligh and Dyer, 1959), pengamatan parameter kimia dan senyawa bioaktif (total vitamin E, total fitosterol, dan skualen) produk biskuit perlakuan terbaik.

\section{Saponifikasi DALMS}

Saponifikasi dilakukan pada DALMS untuk memisahkan asam lemak bebas dengan fraksi tidak tersabunkan. Saponifi-kasi dilakukan dengan modifikasi metode Ahmadi (1997). Tahapan saponifikasi DALMS antara lain: 1)Penimbangan DALMS sebanyak 50 gram kemudian dimasukkan ke dalam Erlenmeyer $1000 \mathrm{ml}$ yang telah ditutup alumuinium foil; 2)Penambahan etanol sebanyak 441,5 ml, asam askorbat sebanyak 2,5 gram, dan $\mathrm{KOH} 50 \%$ sebanyak $50 \mathrm{ml}$; 3)Pemanasan dalam shaker waterbath suhu $65^{\circ} \mathrm{C}$ selama 32 menit; 4)Pendinginan dalam suhu ruang; 5)Pemindahan larutan ke dalam corong pemisah dan ditambahkan heksana sebanyak $750 \mathrm{ml}$ dan akuades sebanyak 1000 $\mathrm{ml}$; 6)Pengocokan lambat dan pendiaman sampai terbentuk dua lapisan; 7)Pemisahan dalam corong pemisah. Fraksi tersabunkan dalam air (bagian bawah corong) dibuang sedangkan fraksi tidak tersabunkan dalam heksana (bagian atas corong) disimpan; dan 
8) Pemisahan fraksi tidak tersabunkan dalam n-heksan dilakukan dengan rotary vacuum evaporator dengan suhu $45^{\circ} \mathrm{C}$ tekanan 200 mbar sehingga diperoleh FTT bebas pelarut.

\section{Pembuatan biskuit}

Pembuatan biskuit dilakukan dengan modifikasi Rahmawati (2014). Prosedur pembuatan biskuit antara lain: 1)Penimbangan bahan-bahan sesuai dengan formulasi yang telah ditentukan; 2)Pencampuran awal yaitu margarin dan gula halus. Pengadukan selama 2-3 menit sampai tercampur; 3)Pencampuran kedua yaitu kuning telur, baking powder, vanili, garam, susu bubuk, dan FTT. Pengadukan selama 23 menit sampai tercampur; 4)Pencampuran ketiga yaitu tepung terigu. Pengadukan selama 2-3 menit sampai adonan kalis; 5)Pemipihan adonan dan pencetakan adonan; dan 6)Pemanggangan adonan pada suhu $\pm 180^{\circ} \mathrm{C}$ selama 10 menit.

\section{HASIL DAN PEMBAHASAN}

\section{Karakteristik DALMS dan FTT}

DALMS merupakan hasil samping (by-product) pemurnian minyak sawit secara fisik. Pada proses pemurnian fisik diperoleh
5\% DALMS dari berat minyak sawit (Puah et al., 2009). Fraksi tidak tersabunkan merupakan hasil dari proses saponifikasi yang masih mengandung beberapa senyawa bioaktif multikomponen. Pada proses saponifikasi, dihasilkan 2 fraksi yaitu fraksi yang bereaksi dengan basa alkali membentuk sabun yang mengendap dan fraksi yang tidak tersabunkan (FTT) (Zulkifli, 2014). Pada penelitian sebelumnya, kadar fraksi tidak tersabunkan dari DALMS yang diperoleh sebesar 2.21\% (Puspitasari, 2013) dan $2.17 \%$ (Latifah, 2015). Pada penelitian ini, kadar FTT dari DALMS yang diperoleh yaitu sebesar $1.93 \%$.

Analisis yang dilakukan pada bahan baku DALMS dan FTT antara lain analisis kadar asam lemak bebas, analisis tingkat oksidasi yang terdiri dari bilangan peroksida dan bilangan $\mathrm{p}$-anisidin, serta karakterisasi senyawa bioaktif DALMS dan FTT meliputi total vitamin E ( $\alpha$-tokoferol, $\alpha$-tokotrienol, $\delta$--tokotrienol, dan $\Upsilon$-tokotrienol), total fitosterol ( $\beta$-sitosterol, stigmasterol, dan kampesterol), dan kadar skualen. Karakteristik DALMS dan FTT dapat dilihat pada Tabel 1.

Tabel 1. Karakteristik DALMS dan FTT

\begin{tabular}{ccccc}
\hline \multirow{2}{*}{ Karakteristik } & \multicolumn{2}{c}{ DALMS } & \multicolumn{2}{c}{ FTT } \\
\cline { 2 - 5 } & Hasil Analisis & Literatur & Hasil Analisis & Literatur \\
\hline Asam Lemak Bebas (\%) & $92.49 \pm 0.001$ & $95.8^{\mathrm{a}}$ & $2.14 \pm 0.00001$ & $1.65^{\mathrm{d}}$ \\
Total Oksidasi (mek/kg) & $6.61 \pm 0.29$ & $11.27 \pm 2.31^{\mathrm{b}}$ & $9.20 \pm 0.32$ & $7.94 \pm 1.92^{\mathrm{e}}$ \\
Bilangan peroksida (mek/kg) & $1.65 \pm 0.08$ & $4.24 \pm 1.48^{\mathrm{b}}$ & $3.06 \pm 0.20$ & $2.81 \pm 0.20^{\mathrm{e}}$ \\
Bilangan p-anisidin (mek/kg) & $3.31 \pm 0.14$ & $2.79 \pm 0.66^{\mathrm{b}}$ & $3.08 \pm 0.07$ & $2.32 \pm 0.66^{\mathrm{e}}$ \\
Senyawa Bioaktif & & & & \\
Kadar Vitamin E (ppm) & $1,491.93$ & $196.50^{\mathrm{c}}$ & $77,147.91$ & $342,375.80^{\mathrm{b}}$ \\
$\alpha$-Tokoferol (ppm) & - & $37.99^{\mathrm{c}}$ & - & $7,493.80^{\mathrm{b}}$ \\
$\alpha$-Tokotrienol (ppm) & 997.67 & $35.97^{\mathrm{c}}$ & $51,589.44$ & $166,700.50^{\mathrm{b}}$ \\
$\delta$-Tokotrienol (ppm) & 120.65 & $4.56^{\mathrm{c}}$ & $6,238.85$ & $32,121.04^{\mathrm{b}}$ \\
Y-Tokotrienol (ppm) & 373.61 & $117.98^{\mathrm{c}}$ & $19,319.61$ & $136,060.44^{\mathrm{b}}$ \\
Total Tokotrienol (ppm) & $1,491.93$ & $158.51^{\mathrm{c}}$ & $77,147.91$ & $334,881.98^{\mathrm{b}}$ \\
Total Fitosterol (ppm) & $6,987.96$ & $7.476 .56^{\mathrm{c}}$ & $361,347.79$ & $85,108.09^{\mathrm{b}}$ \\
$\beta-$ Sitosterol $(\mathrm{ppm})$ & $5,310.83$ & $3.913 .37^{\mathrm{c}}$ & $274,623.58$ & $78,506.40^{\mathrm{b}}$ \\
Stigmasterol (ppm) & 419.03 & $1.774 .66^{\mathrm{c}}$ & $21,667.89$ & $5,254.56^{\mathrm{b}}$ \\
Kampesterol (ppm) & $1,258.10$ & $1.788 .53^{\mathrm{c}}$ & $65,058.32$ & $1,347.13^{\mathrm{b}}$ \\
Skualen (ppm) & $10,172.59$ & $1.092 .38^{\mathrm{c}}$ & $165,979.43$ & $21,018.59^{\mathrm{b}}$ \\
\hline Sumb & & &
\end{tabular}

Sumber: a) Rahmawati (2010); b) Asusti (2015); c) Zulkifli (2014); d) Muchlisyiyah (2013); e) Wahyuli (2015) 
Asam lemak bebas (ALB) adalah asam lemak dalam keadaan bebas dan tidak berikatan lagi dengan gliserol (Pasaribu, 2004). Kadar ALB merupakan bilangan asam suatu minyak yang dihitung berdasarkan berat molekul asam lemak campuran atau asam lemak dominan yang terkandung dalam suatu minyak. Pada penelitian ini asam lemak bebas dinyatakan sebagai asam palmitat. Berdasarkan Tabel 1 menunjukkan bahwa kadar ALB dari DALMS pada penelitian ini sebesar $92.49 \pm 0.001 \%$. Secara umum, kadar ALB dalam DALMS berada pada kisaran diatas $80 \%$. Kadar ALB dalam DALMS dapat dikatakan tinggi dikarenakan DALMS merupakan hasil samping pada proses pemurnian fisik minyak sawit kasar dan masih mengandung asam lemak bebas sekitar 80\% (Puah et al., 2009).

Berdasarkan Tabel 1 menunjukkan bahwa kadar ALB dari fraksi tidak tersabunkan (FTT) pada penelitian ini sebesar $2.14 \pm 0.00001 \%$. Hal ini menunjukkan tingkat penurunan kadar ALB sekitar 90\% dari DALMS. Penurunan tersebut disebabkan oleh proses saponifikasi yang menghilangkan sebagian besar asam lemak bebas yang terikat oleh $\mathrm{KOH}$ (basa alkali) membentuk sabun. Sabun tersebut dibuang setelah proses saponifikasi, sehingga didapatkan fraksi tidak tersabunkan dengan kadar ALB yang rendah. Puspitasari (2013) menyebutkan bahwa proses saponifikasi DALMS secara kimia dapat menurunkan kandungan asam lemak bebas sebesar 94$98 \%$.

Selain mengandung asam lemak bebas, DALMS dan FTT juga mengandung hasil oksidasi dari gliserida (Hammod et al., 2005). Keberadaan peroksida dan aldehid yang merupakan hasil oksidasi primer dan sekunder dari minyak dapat menunjukkan derajat kerusakan minyak. Ketengikan terbentuk oleh aldehid dan keton bukan oleh peroksida. Kenaikan bilangan peroksida hanya indikator bahwa minyak sebentar lagi akan mengalami ketengikan (Ketaren, 1986).

Bilangan peroksida merupakan indeks jumlah lemak atau minyak yang telah mengalami oksidasi. Selain itu bilangan peroksida juga didefinisikan sebagai jumlah peroksida dalam miliekuivalen (mek) oksigen aktif per kg lemak atau dalam 1.000 gram senyawa (Raharjo, 2006). Bilangan peroksida dari DALMS hasil analisis pada penelitian ini sebesar $1.65 \pm 0.08 \mathrm{mek} / \mathrm{kg}$, sementara itu bilangan peroksida dari FTT hasil analisis pada penelitian ini sebesar 3.06 $\pm 0.20 \mathrm{mek} / \mathrm{kg}$

Pengukuran bilangan anisidin bertujuan untuk mengetahui kandungan aldehid dalam minyak sebagai produk sekunder oksidasi paling penting yang berkaitan erat dengan kualitas rasa dan bau (Puspitasari, 2013). Bilangan p-anisidin dari DALMS hasil analisis pada penelitian ini sebesar $3.31 \pm$ $0.14 \mathrm{mek} / \mathrm{kg}$, sementara itu bilangan panisidin dari FTT pada penelitian ini sebesar $3.08 \pm 0.07 \mathrm{mek} / \mathrm{kg}$.

Beberapa komponen senyawa bioaktif yang terdapat dalam DALMS dan FTT yaitu tokoferol, tokotrienol, fitosterol, dan skualen. Musalmah et al. (2005) menambahkan keunggulan DALMS adalah sebagian besar vitamin $\mathrm{E}$ dalam bentuk tokotrienol $(70 \%)$ dan sisanya adalah tokoferol (30\%). DALMS hasil analisis mengandung vitamin $\mathrm{E}$ yang cukup tinggi yaitu sebesar 1,491.93 ppm. Perbedaan kadar vitamin $\mathrm{E}$ diduga disebabkan pada proses pemurnian minyak sawit terutama pada tahap deodorisasi yang berbeda. Kandungan fitosterol dalam DALMS sebesar 6,987.96 ppm. Komposisi fitosterol dalam DALMS terdiri dari $\beta-$ Sitosterol $(76 \%)$, stigmaterol $(6 \%)$, dan kampesterol (18\%). Menurut Hammond dan Tong (2005), perbedaan komposisi penyusun fitosterol dipengaruhi oleh jenis bahan baku dan kondisi proses pemurnian minyak sawit. Skualen merupakan natural lipid yang termasuk dalam kelompok triterpen hidrokarbon yang mengandung 6 buah isoprene (Vazquez et al., 2007). Kadar skualen hasil analisis pada penelitian ini sebesar 10,172.59 ppm. Kadar skualen cukup tinggi pada DALMS tersebut didukung oleh Posada et al., (2007) yang menyatakan bahwa skualen yang terdapat dalam DALMS sebanyak $1.03 \% \quad(\mathrm{~b} / \mathrm{b})$ lebih tinggi dibandingkan dengan minyak nabati lainnya. 
FTT dari DALMS pada penelitian ini mempunyai kandungan vitamin $\mathrm{E}$ sebesar $77,147.91 \mathrm{ppm}$. Senyawa $\alpha$-tokoferol dalam FTT tidak terdeteksi. Hal tersebut diduga dipengaruhi oleh lama penyimpanan bahan baku, selain itu proses pemanasan pada suhu tinggi pada proses deodorisasi menyebabkan tokoferol mengalami kerusakan yang lebih intensif daripada tokotrienol, sehingga tidak dapat terdeteksi pada penelitian ini. Fitosterol (sterol tumbuhan) merupakan penyusun alami tumbuhan dan bagian dari kelompok isoprenoid (Soupas, 2006). Kandungan fitosterol dalam FTT pada penelitian ini didapatkan sebesar 361,347.79 ppm. Secara kimiawi, skualen $\left(\mathrm{C}_{30} \mathrm{H}_{50}\right)$ termasuk hidrokarbon tidak jenuh dengan enam ikatan rangkap, bersifat tidak tersabunkan, berbentuk minyak jernih yang tidak berbau dan tidak berasa (Bahttacahrjee dan Shingal, 2003). Kandungan skualen dalam FTT yang didapatkan dari penelitian ini yaitu sebesar $165,979.43 \mathrm{ppm}$.

\section{Karakteristik fisik biskuit terfortifikasi FTT DALMS}

Parameter fisik yang dianalisis dari biskuit yang terfortifikasi FTT DALMS meliputi hardness (kekerasan), daya patah, daya kembang, densitas kamba, dan warna.

\section{Daya patah}

Daya patah merupakan salah satu faktor yang penting dalam menentukan mutu sebuah biskuit. Daya patah pada bahan pangan menunjukkan ketahanan bahan pangan tersebut terhadap tekanan yang diberikan. Selain itu juga berhubungan dengan tingkat kerenyahan suatu produk. Biskuit terfortifikasi FTT DALMS mempunyai rerata nilai daya patah dengan kisaran antara $3.93-4.53$ N. Hasil rerata nilai daya patah biskuit terfortifikasi FTT DALMS disajikan pada Gambar 1. Nilai daya patah biskuit cenderung semakin menurun seiring dengan meningkatnya penambahan FTT DALMS. Namun nilai daya patah meningkat dari perlakuan $1.5 \%$ ke $2 \%$.

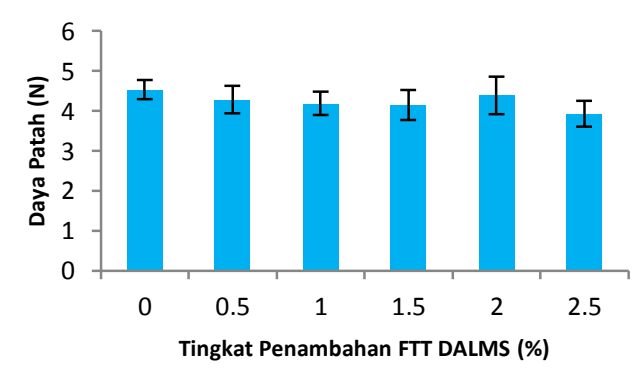

Gambar 1. Grafik rerata daya patah biskuit

Menurut Dewa (2008), faktor-faktor yang mempengaruhi besarnya daya patah pada suatu produk yaitu berat produk dimana semakin berat produk maka daya patah semakin tinggi. Kemudian kadar air dimana dengan adanya kandungan air dalam ronggarongga antar sel suatu bahan dapat menurunkan kekakuan sel sehingga akan menurunkan kerenyahan produk. Selain itu faktor yang berpengaruh yaitu adanya kadar protein dimana protein yang terdenaturasi akan mempengaruhi gugus reaktifnya sehingga gugus reaktifnya akan membuka dan kemudian terjadi pengikatan kembali antara gugus reaktif yang berdekatan sehingga jumlah ikatannya menjadi lebih banyak dan lebih kuat.

\section{Hardness (tingkat kekerasan)}

Produk pangan mempunyai bentuk dan tekstur yang beraneka macam. Hardness merupakan salah satu indikator penting dalam menganalisis tekstur bahan pangan terutama dalam bentuk produk baked seperti roti dan biskuit (Wenzhao et al., 2013). Biskuit terfortifikasi FTT DALMS mempunyai rerata nilai kekerasan (hardness) dengan kisaran antara 357.23 - 634.68 g. Hasil rerata nilai kekerasan (hardness) biskuit terfortifikasi FTT DALMS disajikan pada Gambar 2.

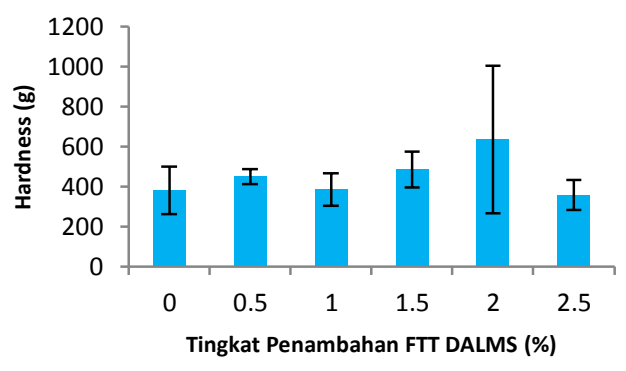

Gambar 2. Grafik rerata hardness biskuit 
Nilai hardness (tingkat kekerasan) pada biskuit cenderung semakin meningkat seiring dengan meningkatnya penambahan FTT DALMS. Namun nilai hardness menurun dari perlakuan $0.5 \%$ ke $1 \%$ serta dari perlakuan $2 \%$ ke $2.5 \%$. Menurut Pratama et al. (2014), nilai kekerasan biskuit yang terukur serta tekstur biskuit akan dipengaruhi oleh komposisi penyusun biskuit, suhu, dan waktu pemanggangan-nya. Selain itu pada penelitian ini diduga bahwa nilai kekerasan juga dipengaruhi oleh tingkat ketebalan biskuit. Biskuit yang dibuat setiap perlakuan diduga mempunyai sedikit perbedaan meskipun telah diukur saat pembuatan. Sehingga biskuit yang lebih tebal diduga mempunyai nilai kekerasan yang lebih tinggi.

\section{Daya kembang}

Daya kembang merupakan parameter produk pangan yang dipengaruhi oleh komposisi bahan, proses pembuatan, dan proses pemanggangan pada biskuit. Daya kembang merupakan rasio antara selisih volume setelah dipanggang dengan volume sebelum dipanggang (Yuwono dan Susanto, 1998). Biskuit terfortifikasi FTT DALMS mempunyai rerata daya kembang dengan kisaran antara $34.52-46.43 \%$. Hasil rerata daya kembang biskuit terfortifikasi FTT DALMS disajikan pada Gambar 3.

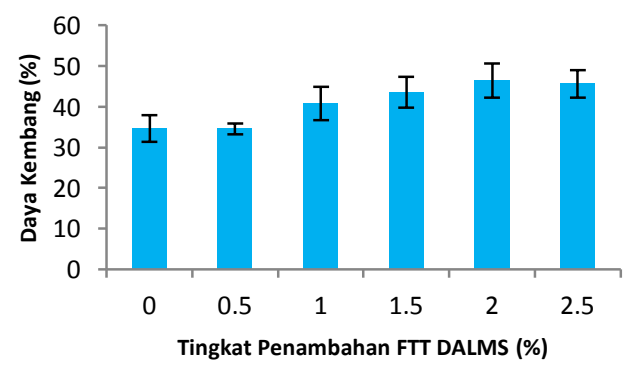

Gambar 3. Grafik rerata daya kembang biskuit

Nilai daya kembang biskuit cenderung semakin meningkat seiring dengan meningkatnya penambahan FTT DALMS. Namun nilai daya kembang sedikit menurun dari perlakuan $2 \%$ ke $2.5 \%$. Salah satu faktor yang mempengaruhi proses pengembangan biskuit yaitu dari proses pemanggangan. Ketika pemanggangan air yang terikat dalam granula pati terlepas saat pemanasan pada suhu tertentu sehingga air menguap dan uap yang terbentuk akan mendesak jaringan sel untuk keluar. Hal tersebut akan menyebabkan terjadinya pe-ngembangan sekaligus pengosongan yang terbentuk rongga-rongga udara pada biskuit yang telah dipanggang (Visita et al., 2014).

\section{Densitas kamba}

Densitas kamba merupakan parameter fisik yang menunjukkan porositas bahan. Densitas kamba adalah perbandingan bobot bahan dengan volume yang ditempatinya, termasuk ruang kosong diantara butiran makanan. dapat diukur dengan menimbang bahan yang menempati wadah sesuai dengan volumenya (Yuwono dan Susanto, 1998). Biskuit terfortifikasi FTT DALMS mempunyai rerata densitas kamba dengan kisaran antara $144.92-161.46 \mathrm{mg} / \mathrm{ml}$. Hasil rerata daya kembang biskuit terfortifikasi FTT DALMS disajikan pada Gambar 4.

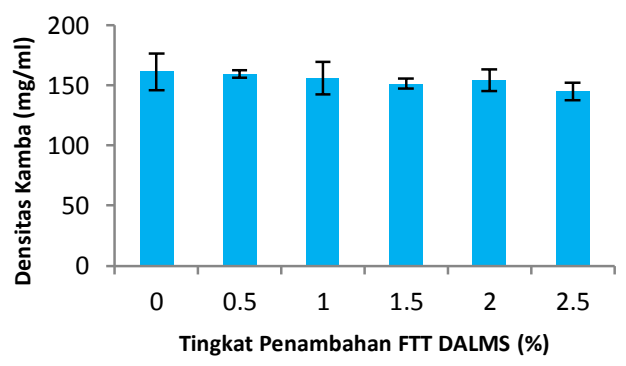

Gambar 4. Grafik rerata densitas kamba biskuit

Nilai densitas kamba biskuit cenderung semakin menurun seiring dengan meningkatnya penambahan FTT DALMS. Namun nilai daya kembang sedikit meningkat dari perlakuan $1.5 \%$ ke $2 \%$ dan kembali menurun dari perlakuan $2 \%$ ke 2.5\%. Densitas kamba semakin kecil menunjukkan bahwa suatu produk mempunyai daya kembang yang besar. Densitas kamba mempengaruhi jumlah bahan yang bisa dikonsumsi dan biaya produksi bahan. Densitas kamba yang cukup tinggi diharapkan dapat mengurangi biaya pengiriman, pengemasan, dan penyimpanan pada biskuit. Bahan dengan densitas kamba kecil akan membutuhkan tempat yang luas dibandingkan dengan densitas kamba yang lebih besar untuk berat yang sama sehingga 
tidak efisien dari segi tempat penyimpanan dan kemasan (Hwang dan Hayakawa, 2006).

\section{Warna - tingkat kekuningan $\left(b^{*}\right)$}

Warna yang dinyatakan dalam koordinat $b^{*}$ menyatakan perbedaan antara biru (-b*) dan kuning $\left(+b^{*}\right)$ dengan kisaran nilai -100 hingga +100 . Nilai warna negatif $(-$ $\left.b^{*}\right)$ pada hasil pembacaan alat menunjukkan bahwa biksuit memiliki warna cenderung kebiruan, sebaliknya jika nilai warna positif $\left(+b^{*}\right)$ pada hasil pembacaan alat maka warna biskuit cenderung memiliki warna kekuningan. Biskuit terfortifikasi FTT DALMS mem-punyai rerata tingkat kekuningan $\left(+b^{*}\right)$ dengan kisaran antara 27.52 - 32.04. Hasil rerata daya kembang biskuit terfortifikasi FTT DALMS disajikan pada Gambar 4.

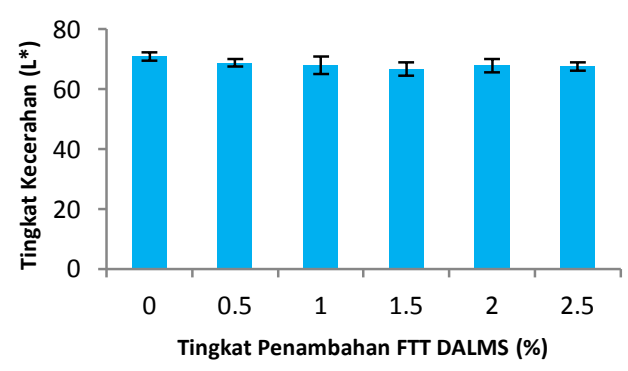

Gambar 5. Grafik Rerata Tingkat kekuningan Biskuit

Rerata tingkat kekuningan $\left(+\mathrm{b}^{*}\right)$ biskuit cenderung semakin meningkat seiring dengan meningkatnya penambahan FTT DALMS. Namun, tingkat kekuningan $\left(+b^{*}\right)$ sedikit menurun dari perlakuan $0 \%$ ke $0.5 \%$. Semakin tinggi nilai warna $\left(b^{*}\right)$ menunjukkan bahwa biskuit yang dihasilkan cenderung memiliki warna kekuningan. Warna kekuningan pada biskuit disebabkan karena adanya penambahan bahan baku seperti margarin, kuning telur, dan FTT DALMS sendiri yang menyumbang pigmen warna karotenoid yaitu kuning kemerahan. Tingkat kekuningan $\left(+b^{*}\right)$ setelah pemanggangan akan menurun. Hal tersebut dapat disebabkan karena selama proses pemanggangan terjadi reaksi antar gula reduksi dengan gugus amina primer pada protein yang disebut reaksi Maillard. Selain itu terjadi reaksi karamelisasi yang timbul karena pemanasan gula yang mencair melampaui titik leburnya sehingga terjadi karamelisasi sukrosa. Hasil reaksi tersebut menghasilkan produk yang berwarna coklat yang dikehendaki pada biskuit dan tingkat kekuningan menurun (Winarno, 2004).

\section{Karakteristik organoleptik biskuit terfortifikasi FTT DALMS}

Penerimaan konsumen terhadap produk merupakan hal yang paling penting dalam menentukan mutu produk, oleh karena itu uji organoleptik yang menggunakan panelis dianggap mempunyai kepekaan untuk menilai mutu berbagai jenis makanan (Kartika et al., 2008). Uji organoleptik yang dilakukan pada penelitian ini yaitu uji hedonik (kesukaan) dan mutu hedonik (skoring).

Uji hedonik dilakukan untuk mengetahui berapa besar kesukaan masyarakat terhadap suatu produk. Parameter yang diamati pada sampel biskuit terfortifikasi FTT DALMS yaitu rasa, tekstur, kerenyahan, aroma, dan warna. Tingkat kesukaan panelis terhadap rasa biskuit terfortifikasi FTT DALMS berada pada skala 2.04 - 4.32 (tidak suka - suka). Tingkat kesukaan panelis terhadap tekstur biskuit terfortifikasi FTT DALMS berada pada skala 3.48 - 3.96 (agak suka - suka). Tingkat kesukaan panelis terhadap kerenyahan biskuit terfortifikasi FTT DALMS berada pada skala 3.52 - 4.00 (suka). Tingkat kesukaan panelis terhadap aroma biskuit terfortifikasi FTT DALMS berada pada skala $2.28-4.32$ (tidak suka suka). Tingkat kesukaan panelis terhadap warna biskuit terfortifikasi FTT DALMS berada pada skala $2.80-3.84$ (agak suka suka).

Uji mutu hedonik atau skoring bertujuan untuk mengetahui repson terhadap sifat-sifat produk yang lebih spesifik, misalnya rasa buah dalam permen, sifat pulen pada nasi, sifat gurih pada kerupuk dan lain sebagainya. Uji skoring biasanya memberikan nilai secara kuantitatif dengan skoring (angka) yang sudah disepakati sebelumnya (Sarastani, 2012). Parameter atau atribut yang digunakan pada uji organoleptik mutu hedonik pada penelitian 
ini yaitu bau menyimpang, rasa menyimpang, rasa enak, kerenyahan, keseragaman warna, dan after taste biskuit. Pengaruh tingkat penambahan FTT DALMS terhadap parameter mutu hedonik pada biskuit disajikan dalam bentuk spider chart yang dapat dilihat pada Gambar 6.

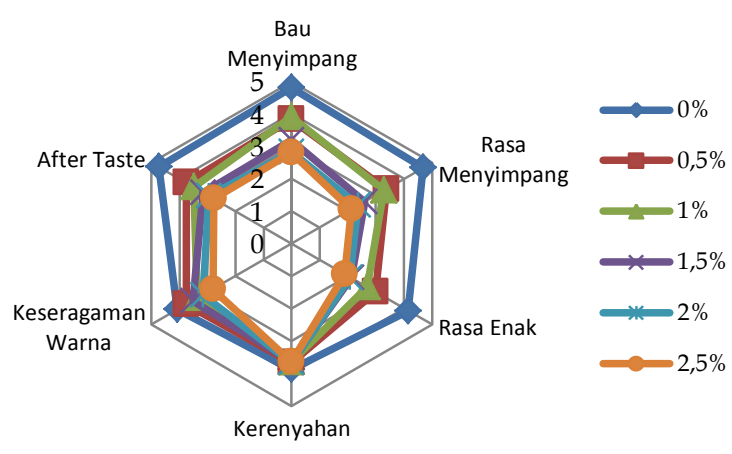

Gambar 6. Pengaruh tingkat penambahan FTT DALMS terhadap parameter mutu hedonik biskuit

Berdasarkan Gambar 6 menunjukkan bahwa secara keseluruhan atribut pada perlakuan tingkat penambahan FTT DALMS $0 \%$ pada biskuit yang digambarkan dengan garis warna biru mendekati garis terluar atau mendekati titik 5, artinya secara keseluruhan biskuit perlakuan 0\% mempunyai mutu hedonik yang baik. Sebaliknya perlakuan tingkat penambahan FTT DALMS $2.5 \%$ pada biskuit yang digambarkan dengan garis warna oranye mendekati garis terdalam atau mendekati titik 0 , artinya secara keseluruhan biskuit perlakuan $2.5 \%$ mempunyai mutu hedonik yang kurang baik.

\section{Karakteristik kimia biskuit terfortifikasi FTT DALMS perlakuan terbaik}

Analisis kimia dilakukan untuk mengetahui informasi nilai gizi dan kandungan senyawa bioaktif pada biskuit perlakuan terbaik. Biskuit dengan penambahan FTT DALMS konsentrasi 0.5\% (b/b) merupakan biskuit perlakuan terbaik pada penelitian ini. Analisis kimia yang dilakukan pada biskuit perlakuan terbaik yaitu analisis proksimat yang terdiri dari analisis kadar air, kadar abu, kadar lemak, kadar protein, kadar karbohidrat, dan serat kasar. Selain itu dilakukan analisis asam lemak bebas serta total oksidasi (bilangan peroksida dan p-anisidin).

Kadar asam lemak bebas dalam biskuit perlakuan terbaik pada penelitian ini yaitu sebesar $2.66 \pm 0.00002 \%$. Menurut Muchtadi (1992), proses hidrolisis menyebabkan terjadinya hydrolytic rancidity yaitu terjadi flavor dan rasa tengik. Namun kadar ALB yang rendah pada biskuit perlakuan terbaik menunjukkan bahwa ketengikan yang rendah. Bilangan peroksida yang terukur dalam biskuit perlakuan terbaik yaitu sebesar $2.16 \pm 0.08 \mathrm{mek} / \mathrm{kg}$. Sementara bilangan $\mathrm{p}$ anisidin yang terukur dalam biskuit perlakuan terbaik yaitu sebesar $2.79 \pm 0.03$ $\mathrm{mek} / \mathrm{kg}$. Sehingga didapatkan total oksidasi pada biskuit perlakuan terbaik yaitu sebesar $7.10 \pm 0.19 \mathrm{mek} / \mathrm{kg}$. Hasil analisis kimia (proksimat) biskuit perlakuan terbaik $(0.5 \%)$ dan syarat mutu biskuit menurut SII 0177-90 disajikan pada Tabel 2.

Tabel 2. Karakteristik kimia biskuit terfortifikasi FTT DALMS perlakuan terbaik

\begin{tabular}{lcl}
\hline \multicolumn{1}{c}{ Parameter } & $\begin{array}{c}\text { Hasil } \\
\text { Analisis }\end{array}$ & $\begin{array}{c}\text { Syarat } \\
\text { Mutu } \\
\text { Menurut SII } \\
0177-90^{\mathrm{a}}\end{array}$ \\
\hline Kadar Air (\%) & $1.81 \pm 0.06$ & Maks 5 \\
Kadar Abu (\%) & $2.10 \pm 0.06$ & Maks 1.6 \\
K. Lemak (\%) & $27.98 \pm 0.54$ & Min 10 \\
K. Protein (\%) & $8.04 \pm 0.13$ & Min 9.5 \\
K. Karbohidrat (\%) & $60.07 \pm 0.66$ & Min 70 \\
Serat Kasar (\%) & $0.22 \pm 0.02$ & Maks 0.55 \\
Total Kalori (kkal) & 524.26 & Min 400 \\
\hline Sumber:a) Dewan & Standarisasi Nasional
\end{tabular}

Sumber: a) Dewan Standarisasi Nasional (1994) dalam Rahmi (2004)

\section{Karakterisasi senyawa bioaktif biskuit terfortifikasi FTT DALMS perlakuan terbaik}

Analisis senyawa bioaktif dilakukan pada biskuit perlakuan terbaik dengan penambahan FTT DALMS $0.5 \%$ (b/b) untuk mengetahui karakterisasi senyawa bioaktif pada biskuit. Kandungan senyawa bioaktif pada biskuit perlakuan terbaik dapat dilihat pada Tabel 3. 
Tabel 3. Kandungan senyawa bioaktif pada biskuit terfortifikasi FTT DALMS perlakuan terbaik

\begin{tabular}{ccc}
\hline \multirow{2}{*}{ Senyawa Bioaktif } & \multicolumn{2}{c}{ Hasil Analisis } \\
\cline { 2 - 3 } & $\mathrm{ppm}$ & \% relatif \\
\hline Kadar Vitamin E & 405.58 & \\
$\alpha$-tokoferol & - & - \\
$\alpha$-tokotrienol & 147.19 & 36.29 \\
$\delta$-tokotrienol & 190.30 & 46.92 \\
$\Upsilon$-tokotrienol & 68.09 & 16.79 \\
Total Tokotrienol & 405.58 & 100.00 \\
Total Fitosterol & $6,613.52$ & \\
$\beta$-sitosterol & $5,848.45$ & 88.43 \\
Stigmasterol & 143.97 & 2.18 \\
Kampesterol & 621.09 & 9.39 \\
Skualen & $3,284.50$ & \\
\hline
\end{tabular}

Berdasarkan Tabel 3 dapat diketahui bahwa biskuit perlakuan terbaik $(0.5 \%)$ pada penelitian ini mempunyai kandungan vitamin E sebesar $405.58 \mathrm{ppm}$. Vitamin E adalah vitamin yang larut dengan baik dalam lemak dan mampu melindungi tubuh dari radikal bebas. Vitamin E juga berfungsi mencegah penyakit hati, mengurangi kelelahan, membantu memperlambat penuaan karena vitamin $\mathrm{E}$ berperan dalam suplai oksigen ke darah sampai dengan ke seluruh organ tubuh. Vitamin $\mathrm{E}$ juga menguatkan dinding pembuluh kapiler darah dan mencegah kerusakan sel darah akibat racun (Papas, 2008).

Senyawa bioaktif fitosterol dalam biskuit perlakuan terbaik memiliki kandungan sebesar 6,613.52 ppm. Fitosterol mampu mengurangi kadar kolesterol total dan LDL kolesterol di dalam darah. Dosis $2-$ 3 gram fitosterol per hari dapat mengurangi LDL kolesterol sekitar 5-15\% (Rafia, 2013). Kehadiran $\beta$-sitosterol di dalam hati akan memercepat rusaknya enzim spesifik yang dibutuhkan hati untuk memproduksi kolesterol, atau secara tidak langsung menghambat pembentukan kolesterol di hati dan menghambat absorbsi kolesterol oleh darah (Ostlund et al., 2003).

Kandungan skualen yang terdapat pada biskuit hasil penelitian ini yaitu sebesar 3,284.50 ppm. Fungsi utama skualen adalah melindungi permukaan kulit dari sinar ultraviolet dan sumber radiasi lainnya. Oleh karena itu, senyawa ini sering digunakan sebagai salah satu komposisi dalam perawatan kulit. Skualen juga menjadi salah satu komposisi dalam suplemen untuk meningkatkan kekebalan tubuh. Selain itu skualen dimanfaatkan sebagai bahan untuk detoksifikasi, antistatic, bactericidal dan fungicidal agent (Bahttacahrjee and Shingal, 2003). Apabila mengonsumsi skualen, skualen tersebut akan bereaksi dengan cairan tubuh atau air $\left(\mathrm{H}_{2} \mathrm{O}\right)$ di dalam tubuh. Skualen dapat membantu memenuhi kebutuhan oksigen yang diperlukan pada proses metabolisme sel tubuh karena bereaksi dengan air atau cairan tubuh (Vazquez et al., 2007).

\section{KESIMPULAN}

Hasil penelitian menunjukkan bahwa perlakuan tingkat penambahan FTT DALMS dengan konsentrasi penambahan $0 \%, 0.5 \%$, $1 \%, 1.5 \%, 2 \%$, dan $2.5 \%$ (b/b) berpengaruh nyata terhadap daya kembang dan tingkat kekuningan $\left(+b^{*}\right)$ biskuit. Namun tidak berpengaruh nyata terhadap hardness (tingkat kekerasan), daya patah, dan densitas kamba. Biskuit perlakuan terbaik didapatkan pada perlakuan tingkat penambahan FTT DALMS sebesar $0,5 \% \quad(\mathrm{~b} / \mathrm{b})$. Biskuit perlakuan terbaik mengandung senyawa bioaktif antara lain: $\alpha$-tokotrienol sebesar $147.19 \mathrm{ppm}, \delta$-tokotrienol sebesar 190.30 ppm, $\Upsilon$-tokotrienol sebesar $68.091 \mathrm{ppm}, \beta-$ sitosterol sebesar 5,848.45 ppm, stigmasterol sebesar 143.97 ppm, dan kampesterol sebesar 621.09 ppm, dan kadar skualen sebesar $3,284.50 \mathrm{ppm}$.

\section{DAFTAR PUSTAKA}

Ahmadi, K. (1997). Aktivasi zeolit alam dan penggunaannya untuk pemurnian tokoferol dari distilat asam lemak minyak sawit [Tesis]. Yogyakarta: Program Pascasarjana UGM.

Asusti. (2015). Fortifikasi mikrokapsul fraksi tidak tersabunkan dari distilat asam lemak minyak sawit (DALMS) pada 
Biskuit [Skripsi]. Fakultas Teknologi Pertanian, Universitas Brawijaya, Malang.

Bligh, E. G., \& Dyer, W. J. (1959). A rapid method of total lipid extraction and purification. Canadian journal of biochemistry and physiology,37(8), 911-917.

Dewa, I. G. P. J. (2008). Karakteristik biskuit berserat hasil suplementasi tepung ampas tahu dan tepung ampas kelapa [Skripsi]. Fakultas Teknologi Pertanian, Universitas Brawijaya Malang.

Estiasih, T., Ahmadi, K., Widyaningsih, T. D., Maligan, J. M., Mubarok, A. Z., Zubaidah, E., ... \& Puspitasari, R. (2013). Bioactive compounds of palm fatty acid distillate (PFAD) from several palm oil refineries. Advance Journal of Food Science and Technology, 5(9), 1153-1159.

Hadi, M. N. (2007). Kajian formulasi lighter biskuit dalam pengembangan produk baru di PT Arnott's Indonesia [Skripsi]. Departemen Ilmu dan Teknologi Pangan, Fakultas Teknologi Pangan. Institut Pertanian Bogor.

Hammond, E.G., Johnson, L.A., \& Su, C. (2005). Soybean oil. bailey's industrial oil and fat products, $6^{\text {th }}$ Edition, Six Volume Set. John Wiley \& Sons Inc., New York

Hwang, M. P., \& Yakawa, K. I. H. (1980). Bulk densities of cookies undergoing commercial baking processes. Journal of Food Science, 45(5), 1400-1402.

Kartika, B., Hastuti, P., \& Supartono, W. (2008). Pedoman uji inderawi bahan pangan. Yogyakarta: UGM Press.

Ketaren, S. (1986). Pengantar teknologi minyak dan lemak pangan. Jakarta: UIPress.

Latifah, N. (2014). Mikroenkapsulasi fraksi tidak tersabunkan (FTT) distilat asam lemak minyak sawit (DALMS) menggunakan metode pengeringan semprot [Skripsi]. Fakultas Teknologi Pertanian, Universitas Brawijaya Malang
Liu, D., Shi, J., Posada, L. R., Kakuda, Y., \& Xue, S. J. (2008). Separating tocotrienols from palm oil by molecular distillation. Food Reviews International, 24(4), 376-391.

Muchlisyiyah, J. (2013). Karakterisasi senyawa bioaktif distilat asam lemak minyak sawit (DALMS) dari beberapa industri pemurnian serta peningkatan skala saponifikasi pada separasi fraksi tidak tersabunkan DALMS [Tesis]. Fakultas Teknologi Pertanian, Universitas Brawijaya Malang.

Musalamah, M., Nizam, M.Y., Noor Aini, A.H., Azian, A.I., Gapor, M.T., \& Wah Ngah, W.Z. (2005). Comparative effect of palm vitamin e and alfa tocopherol on heading and wound tissue antioxidant enzyme level in diabetic rats. Lipids, 40, $575-580$.

Ostlund Jr, R. E., Racette, S. B., \& Stenson, W. F. (2003). Inhibition of cholesterol absorption by phytosterol-replete wheat germ compared with phytosteroldepleted wheat germ. The American journal of clinical nutrition,77(6), 1385-1389.

Papas, A. M. (2008). Vitamin E: a new perspective. Nutri News, 9(1), 1-8.

Pasaribu, N. (2004). Minyak buah kelapa sawit. Universitas Sumatera Utara.

Posada, L. R., Shi, J., Kakuda, Y., \& Xue, S. J. (2007). Extraction of tocotrienols from palm fatty acid distillates using molecular distillation. Separation and Purification Technology, 57(2), 220229.

Pratama, R. I., Rostini, I., \& Liviawaty, E. (2014). Karakteristik biskuit dengan penambahan tepung tulang ikan Jangilus (Istiophorus SP.). Jurnal akuatika, 5(1), 30 - 39.

Puah, C., Choo, Y., Ma, A., \& Chuah, C. (2007). The effect of physical refining on palm vitamin $\mathrm{E}$ (tocopherol, tocotrienol and tocomonoenol). American Journal of Applied Sciences, 4(6), 374-377.

Puspitasari, R. (2013). Optimasi saponifikasi distilat asam lemak minyak sawit 
(DALMS) pada separasi fraksi tidak tersabunkan mengandung senyawa bioaktif multi komponen [Skripsi]. Fakultas Teknologi Pertanian, Universitas Brawijaya Malang.

Raharjo, S. (2006). Kerusakan oksidatif pada makanan. Yogyakarta: Gadjah Mada University Press.

Rahayu, W. P. (2001). Penuntun praktikum penilaian organoleptik. Jurusan Teknologi Pangan dan Gizi, Institut Pertanian Bogor.

Rahmawati, A. (2010). Optimasi kristalisasi pelarut suhu rendah pada pembuatan fraksi kaya tokotrienol dari DALMS [Skripsi]. Fakultas Teknologi Pertanian Universitas Brawijaya Malang.

Rahmawati, W. E. (2014). Fortifikasi kalsium cangkang telur pada pembuatan cookies (kajian konsentrasi tepung cangkang telur dan baking powder) [Skripsi]. Universitas Brawijaya Malang.

Rahmi, E. (2004). Pengaruh perubahan suhu oven terhadap mutu produk biskuit kelapa di PT. Mayora Indah [Skripsi]. Institut Pertanian Bogor.

Salimon, J., Abdullah, B. M., \& Salih, N. (2012). Saponification of Jatropha curcas seed oil: optimization by Doptimal design. International Journal of Chemical Engineering, 2012.

Sarastani, D. (2012). Penuntun praktikum analisis organoleptik. Institut Pertanian Bogor.

Soupas, L. (2006). Oxidative stability of phytosterols in food models and foods [Dissertasion] Agriculture and Forestry of the University of Helsinki.

Subagjo, A. (2007). Manajemen pengolahan kue dan roti. Yogyakarta: Graha Ilmu.
Ulum, M. \& Hariyanto. (2015). Statistik kelapa sawit Indonesia 2014. Jakarta: Badan Pusat Statistik.

Vazquez, L., Torres, C. F., Fornari, T., Señoráns, F. J., \& Reglero, G. (2007). Recovery of squalene from vegetable oil sources using countercurrent supercritical carbon dioxide extraction. The Journal of supercritical fluids, 40(1), 59-66.

Visita, B. F., \& Putri, W. D. R. (2013). Pengaruh penambahan bubuk mawar merah (Rosa damascene Mill) dengan jenis bahan pengisi berbeda pada cookies. Jurnal Pangan dan Agroindustri, 2(1), 39-46.

Wenzhao, L., Guangpeng, L., Baoling, S., Xianglei, T., \& Xu, S. (2013). Effect of Sodim Stearoyl Lactylate on Refinement of Crisp Bread and The Microstructure of Dough. Journal of Food Science and Technology, 5(6), 682-687.

Winarno, F. G. (2004). Kimia pangan dan gizi. Jakarta: Gramedia Pustaka Utama.

Yuwono, S. S. \& Susanto, T. (1998). Pengujian fisik pangan. Fakultas Teknologi Pertanian, Universitas Brawijaya Malang.

Zeleny, M. (1982). Multiple criteria decision making. New York: Mc Graw Hill Book Company Inc.

Zulkifli, M. (2014). Optimasi saponifikasi distilat asam lemak minyak sawit (DALMS) tanpa etanol [Skripsi]. Fakultas Teknologi Pertanian, Universitas Brawijaya Malang.

Zulkifli, M., \& Estiasih, T. (2014). sabun dari distilat asam lemak minyak sawit: kajian pustaka [In Press Oktober 2014]. Jurnal Pangan dan Agroindustri, 2(4), 170-177. 